\begin{tabular}{|l|l|l||}
\hline \multicolumn{2}{|c|}{ PublisherInfo } \\
\hline \hline PublisherName & $:$ & BioMed Central \\
\hline \hline PublisherLocation & $:$ & London \\
\hline \hline PublisherImprintName & $:$ & BioMed Central \\
\hline \hline
\end{tabular}

\title{
Putting the sea into cancer therapy
}

\begin{tabular}{|l|l|l||}
\hline \multicolumn{2}{|c|}{ ArticleInfo } \\
\hline \hline ArticleID & $:$ & 4164 \\
\hline \hline ArticleDOI & $:$ & $10.1186 /$ gb-spotlight-20010806-01 \\
\hline \hline ArticleCitationID & $:$ & spotlight-20010806-01 \\
\hline \hline ArticleSequenceNumber & $:$ & 235 \\
\hline \hline ArticleCategory & $:$ & Research news \\
\hline \hline ArticleFirstPage & $:$ & 1 \\
\hline \hline ArticleLastPage & $:$ & 2 \\
\hline \hline & & RegistrationDate : 2001-08-06 \\
ArticleHistory & $:$ & OnlineDate \\
\hline \hline ArticleCopyright & $:$ & BioMed Central Ltd2001-08-06 \\
\hline \hline ArticleGrants & $:$ & \\
\hline \hline ArticleContext & $:$ & 130592211 \\
\hline \hline
\end{tabular}




\section{Tudor Toma}

Email: ttoma@mail.dntis.ro

Under normal circumstances DNA mutations occurring in a cell are fixed by the cell's own DNArepair mechanisms. These include nucleotide-excision repair (NER), which removes damaged sections of DNA and replaces them with the correct sequence. In the August Nature Medicine, Yuji Takebayashi and colleagues from the US National Cancer Institute, Bethesda, Maryland demonstrate a new cellkilling mechanism mediated by NER that can be exploited to improve cancer therapy (Nature Med 2001, 7:961-966).

Takebayashi et al. studied the effects of the novel anticancer drug ecteinascidin 743 (Et743), a natural product isolated from the Caribbean sea squirt (Ecteinascidia turbinate), on cells with the chromosome alterations seen in Xeroderma pigmentosum - a hereditary condition in which the affected individual is chronically hypersensitive to UV light. They found that Et743 alters the NER process, and rather than repairing the damaged DNA it causes the NER machinery to create lethal breaks in the DNA, thus killing cells.

This is a unique and previously unrecognised mechanism of killing cancer cells and the authors suggest that Et743 could be of considerable use in the treatment of cisplatin-resistant ovarian carcinoma, a cancer which exhibits enhanced NER activity.

\section{References}

1. Takebayashi Y, Pourquier P, Zimonjic DB, Nakayama K, Emmert S, Ueda T, Urasaki Y, Kanzaki A, Akiyama Si, Popescu N et al.: Anitproliferative activity of ecteinascidin 743 is dependent upon transcription-coupled nucleotide-excision repair.Nature Med 2001, 7:961-966, [http://medicine.nature.com]

2. National Cancer Institute, [http://www.nci.nih.gov]

3. The Xeroderma Pigmentosum Society, [http://www.xps.org/]

This PDF file was created after publication. 